\title{
Aboveground Live Carbon Storage in Woody Agroforestry Systems of Sokoru District, Jimma Zone, Southwest Ethiopia
}

\author{
Guta Waktole Weyesa \\ Genetic Resources Access and Benefit Sharing Directorate, Ethiopian Biodiversity Institute (EBI), Addis Ababa, Ethiopia
}

\section{Email address:}

waaqtoleegutaa@gmail.com

\section{To cite this article:}

Guta Waktole Weyesa. Aboveground Live Carbon Storage in Woody Agroforestry Systems of Sokoru District, Jimma Zone, Southwest Ethiopia. International Journal of Economy, Energy and Environment. Vol. 4, No. 1, 2019, pp. 11-17. doi: 10.11648/j.ijeee.20190401.12

Received: January 17, 2019; Accepted: February 16, 2019; Published: March 5, 2019

\begin{abstract}
There is a growing interest in the role of different types of land use systems in stabilizing the atmospheric $\mathrm{CO}_{2}$ concentration, reducing the $\mathrm{CO}_{2}$ emissions and on increasing the carbon sink of forestry and agroforestry systems. Agroforestry has potential to mitigate climate change and help farmers to adapt the impacts of climate change. Different types of agroforestry systems such as homegarden, cropland and pastureland have great role in storing carbon and stabilizing the climate change by absorbing $\mathrm{CO}_{2}$ from the atmosphere. The main objective of this study was to investigate aboveground live carbon storage in agroforestry of Sokoru District, Jimma Zone. The study was conducted from February to May, 2018. Descriptive statistics and one way ANOVA were used to analyze the population density, above ground live biomass, carbon storage, tree height and diameter at breast height and basal area for each tree was calculated. Aboveground live biomass of each tree was determined by using the revised nondestructive equation. The amount of carbon stored in each tree was estimated at $50 \%$ of the aboveground live biomass hence $5.54 \mathrm{t}$, and in homegarden, $9 \mathrm{t}$ in cropland and $3.47 \mathrm{t}$ pastureland carbon was stored. From three land use types the highest amount of carbon was stored in cropland followed by homegarden and pastureland. Eventually, the study revealed that the woody species found in different agroforestry system of the study area have great role in carbon storage and $\mathrm{CO}_{2}$ sequestration. Thus all stakeholders should focus on conservation of trees and shrubs found agricultural landscapes.
\end{abstract}

Keywords: Agro-Forestry, Land Use Types, Carbon Storage, Woody Species, Homegarden, Cropland, Pastureland and Carbon Storage

\section{Introduction}

Global emissions of carbon dioxide to atmosphere have been increasing for about 140 years since the beginning of the industrial revolution [1]. Concentration of carbon dioxide in the atmosphere has increased and approached $360 \mathrm{ppm}$ by the end of year 2000. It is estimated that the future doubling of $\mathrm{CO}_{2}$ in atmosphere to about $700 \mathrm{ppm}$ will risk an accompanying greenhouse effect rise of $1.5-4.0^{\circ} \mathrm{C}$ in mean global surface temperature [2].

The woodlands of Africa cover about $54 \%$ of the continent and support some $64 \%$ of its population [3]. At this time, these woodlands are under serious threats mostly by human activities [4] and the impact of climate change [5]. In face of this significant concern, the main concrete solution suggested were forest plantation [6], the effectiveness of protected sites in biodiversity conservation.

As forests are converted to agricultural fields and urban areas, the amount of carbon dioxide in the atmosphere become increased. The concentration of carbon dioxide is increasing and a trend believed to impact the earth's climate [7]. It is thought that land use change is responsible for 20$30 \%$ of the net increase of carbon emission [8].

Agroforestry systems are amongst the most important processes that determine the terrestrial ecosystem carbon balance [9]. The magnitude and dynamics of the forest carbon sink depend on carbon allocation to many storage pools [10]. Agroforestry systems play an important role in various goods and services including enhancement of carbon storage and organic matter conservation of above and below 
ground biodiversity and improvement of soil fertility and structure [11].

Agroforestry has played an important role in increasing land productivity and enhancing livelihoods in developed and developing countries [12]. Although carbon sequestration and afforestation and reforestation of degraded natural resource have long been considered significant in climate change mitigation, agroforestry offers distinct advantages [13]. The planting of trees along with crops on cropland improves soil fertility, controls and prevents soil erosion, controls water logging, checks acidification and eutrophication of streams and rivers enhances local biodiversity by decreasing pressure on forests for fuel and provides fodder for livestock [14].

The main objective of this study is to investigate aboveground live carbon storage in different agroforestry systems of Sokoru district, Jimma Zone, Southwest Ethiopia. Although the possible benefits of agroforestry in carbon sequestration have been conceptually discussed and field measurements to validate these concepts have been undertaken to significant extent, there is no any report on the potential of agroforestry in carbon storage from Sokoru district. Therefore; this study was designed to fill this knowledge gap and to answer the following questions: How much carbon is stored in aboveground live woody species biomass in Agroforestry systems of Sokoru district? Which agroforestry system stores more carbon in aboveground live biomass?

\subsection{Ways in Which Woody Species can Store Carbon}

Carbon is stored in pools of aboveground biomass like timber, branches and belowground biomass like roots, soil microorganisms and organic carbon in soil [15]. Trees have greater capacity to store carbon than annual crops and grasses on pastures. Agroforestry systems, therefore present better option for carbon sequestration [16].

\subsection{Measurement of Carbon Dioxide in the Atmosphere}

Since pioneer measurements of turbulent fluxes over tall vegetation, eddy-covariance (EC) has been widely used as a standard method for the estimation of seasonal fluctuations in carbon exchange between forest ecosystems and the atmosphere [17]. In conjunction with forest inventories [18], data have greatly improved the understanding of the terrestrial carbon budget and its climate sensitivity at local to global scales [17, 19].

There is a growing interest of different types of land use systems in sequestering the atmospheric $\mathrm{CO}_{2}$ concentration or on increasing the carbon sink of forestry and agroforestry systems. Agro-forestry has been recognized as a means to reduce $\mathrm{CO}_{2}$ emissions as well as enhancing carbon sinks. The role agroforestry in carbon cycles is well recognized and forests are large sinks of carbon [20]. There is considerable interest to increase the carbon storage capacity of agroforestry land-use practices such as afforestation, reforestation, and natural regeneration of forests, silvicultural systems and agro forestry [21].

\section{Methods and Materials}

\subsection{The Study Area and Period}

This study was conducted in Sokoru district of Jimma Zone from February - May, 2018. Sokoru district is found in Oromia Regional State, Jimma Zone (Figure 1) at about100 $\mathrm{km}$ East of Jimma town and $156 \mathrm{~km}$ southwest of Addis Ababa. The altitude of the district lies in the range of 900$2,300 \mathrm{~m}$ above sea level. The district is located between $7^{\circ}$ $55^{\prime}-7^{\circ} .92^{\prime} \mathrm{N}$ latitude and $37^{\circ} 25^{\prime}-37^{\circ} .42^{\prime}$ E longitude [22].

\subsection{Methods}

\subsubsection{Sampling Design}

A transect line of $24 \mathrm{~km}$ long with $2 \mathrm{~km}$ buffer $(1 \mathrm{~km}$ on the left and $1 \mathrm{~km}$ on the right of the transect) was established across different land use types (homegarden, pasture and cropland). The elevation of the study area ranges from 1679 - $1934 \mathrm{~m}$ above sea level. Of 42 total sample plots, 14 sample plots of $100 \mathrm{~m} \times 100 \mathrm{~m}$ were established in cropland and 14 sample plots of $100 \mathrm{~m} \times 100 \mathrm{~m}$ were established in cropland while 14 plots of $20 \mathrm{~m} \times 20 \mathrm{~m}$ were put in the homegardens (the homegarden was standardized to hectare for later comparison with the two land use types).

\subsubsection{Data Collection}

Stem count of woody species in pasture and cropland has been taken from each one hectare plot $(100 \mathrm{~m} \times 100 \mathrm{~m})$ whereas the stem count from homegarden agroforestry was taken from $20 \mathrm{~m} \times 20 \mathrm{~m}$ plot (this was later converted to hectare in order to compare with cropland and pastureland). The circumference of each stem with diameter at breast height $(\mathrm{DBH}) \geq 5 \mathrm{~cm}$, height $\geq 1.3 \mathrm{~m}$ was recorded from each plot [23]. The height of all individuals was also recorded using Clinometers. For the stem abnormalities, RAINFOR protocol was followed [24]. Latitude, longitude and altitude of the study site were recorded by using Global Positioning System (GPS). Samples of woody species (including their local names) were recorded. All woody specific gravity of each tree species was taken from global wood density data base developed by [25]. The samples were transported to Jimma University herbarium for identification. Flora of Ethiopia and Eritrea were used for the identification of species in the herbarium.

\subsubsection{Carbon Storage}

Aboveground live biomass of each tree was calculated by using the revised nondestructive allometric equation [26].

$$
\mathrm{AGB}=0.0673\left(\rho \mathrm{D}^{2} \mathrm{H}\right)^{0.976}
$$

Where, $\rho=$ wood specific gravity, $\mathrm{D}=$ diameter at breast height, $\mathrm{H}=$ height. The amount of carbon stored in aboveground live biomass of each woody species was estimated at $50 \%$ of the aboveground live biomass (AGB). The amount of $\mathrm{CO}_{2}$ sequestered by the tree was calculated by 
multiplying the amount of carbon in the biomass by 3.67 (which is the ratio of the atomic mass of $\mathrm{CO}_{2}(44.01)$ to the atomic mass of carbon (12)) [26].

Analysis of Variance (one way ANOVA) of SPSS version
20 was used to determine the variation among different agroforestry systems in carbon storage. The data were log transformed as to maintain the normal distribution.

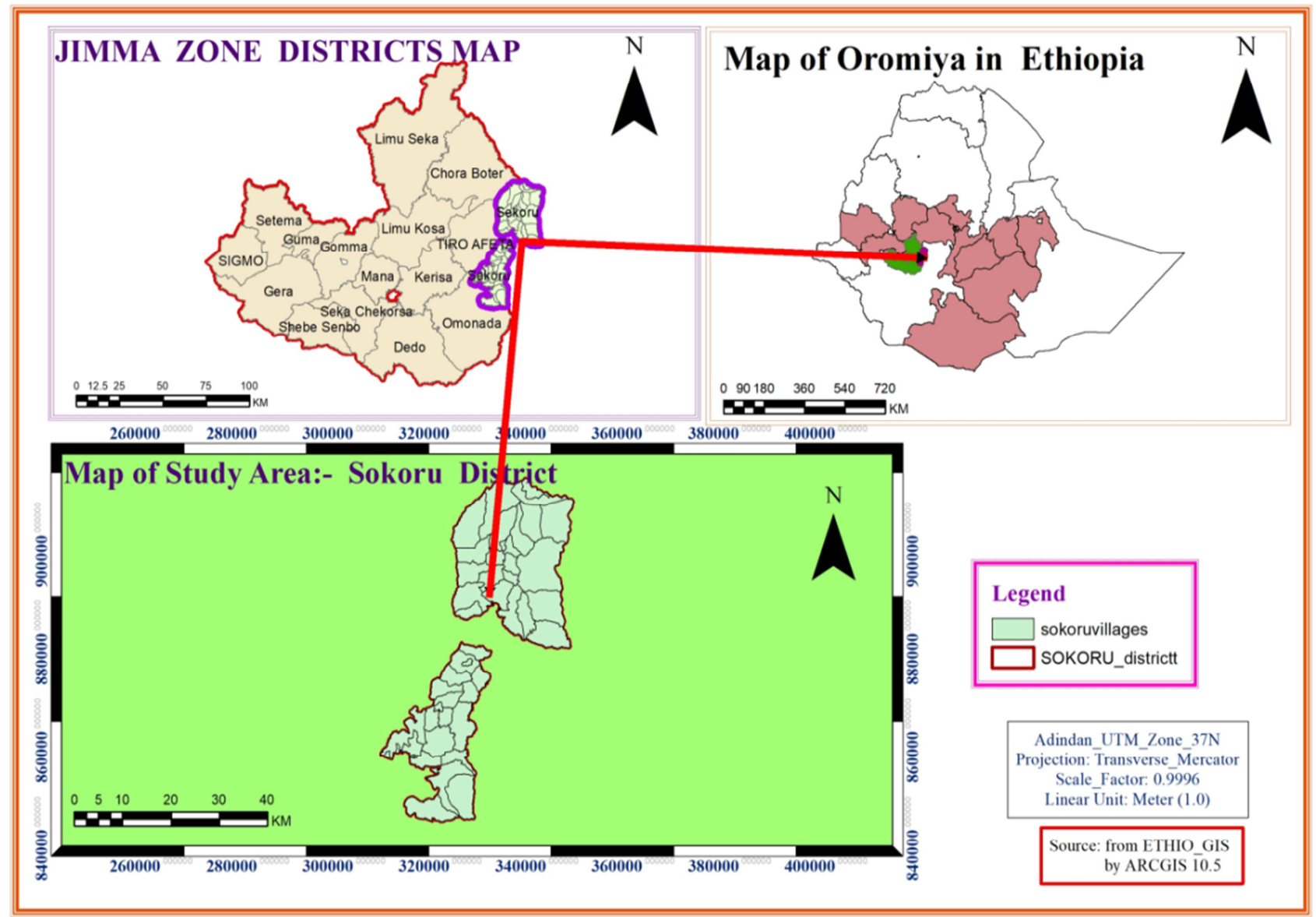

Figure 1. Location map of the study area (Source: from ETHIO-GIS).

\section{Results and Discussions}

\subsection{Results}

\subsubsection{Carbon Stored and Sequestered in Agroforestry of the Study Area}

Of total calculated from the study area, about $20.331 \mathrm{t}$, $33.123 \mathrm{t}$ and $12.7 \mathrm{t}$ was stored in homegarden, cropland and pastureland respectively. Totally $66.17 \mathrm{t} \mathrm{CO}_{2}$ were estimated from the three land uses and croplands stored sequestered high amount of carbon dioxide and followed by homegardens and pasturelands (Table 1).

Table 1. Summary of $A G C$ and $\mathrm{AGCO}_{2}$ in three land use types of Sokoru District; April, 2018.

\begin{tabular}{lll}
\hline Land use type & AGC t/ha & $\mathbf{C O}_{\mathbf{2}} \mathbf{t} / \mathbf{h a}$ \\
\hline Homegarden & 5.539 & 20.331 \\
Cropland & 9.025 & 33.123 \\
Pastureland & 3.465 & 12.7 \\
Total & 18.03 & 66.17 \\
\hline
\end{tabular}

Totally 18.03 tones/ha AGC were estimated from the three land uses and croplands stored high amount of carbon and followed by homegardens and pasturelands (Figure 2).

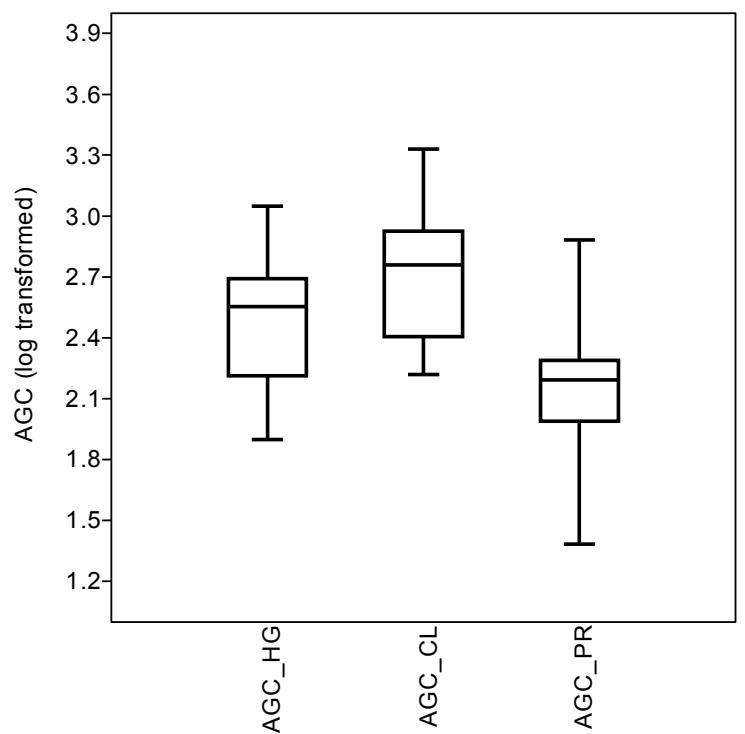

Figure 2. Box plot showing AGC storage in each land use type (cropland, pastureland and homegarden) of Sokoru District; April, 2018. 
There was a significance difference in AGC storage amongst the three land use types of the study area $(\mathrm{F}=6.129$, $\mathrm{P}=0.005$ ) (Table 2). Tuky's multiple comparison showed that there was significant variation $(\mathrm{P}=0.003)$ between Crop and Pastureland in carbon storage (Table 3 ).

Table 2. Analysis of variance (ANOVA) showing variation in aboveground live carbon storage among the three agroforestry of Sokoru District; April, 2018.

\begin{tabular}{llllll}
\hline & SS & df & MS & F & P \\
\hline Between groups: & 1.695 & 2 & 0.847502 & 0.129 \\
Within groups: & 5.39298 & 39 & 0.138281 & \\
Total: & 7.08798 & 41 & & \\
\hline
\end{tabular}

Table 3. Summary of one way ANOVA for comparison of AGC of the three land use types (HG =Homegarden, CL =Cropland, PR = Pastureland) of Sokoru District; April, 2018.

\begin{tabular}{llll}
\hline & AGC of HG & AGC of CL & AGC of PR \\
\hline AGC of HG & & 0.3221 & 0.1191 \\
AGC of CL & 2.062 & & 0.003 \\
AGC of PR & 2.868 & 4.929 & \\
\hline
\end{tabular}

\subsubsection{Aboveground Live Carbon Storage in Different Land Use Types}

The top seven known species by storing carbon and sequestering $\mathrm{CO}_{2}$ in homegarden were C. africana, A. indica,
M. indica, C. macrostachyus, G.robusta, C.lusitanica and E. bureccei. Comparatively, C. africana, and A. indica played very important role than any other woody species found in homegarden (Figure 3).

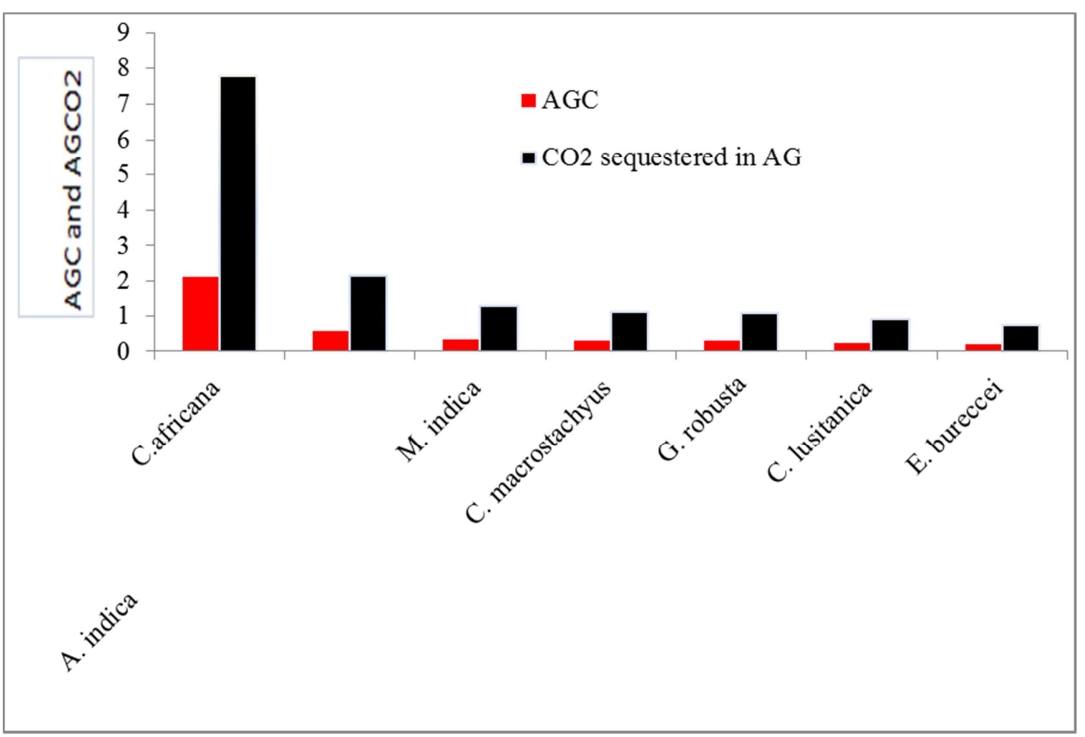

Figure 3. $\mathrm{AGC}$ and $\mathrm{CO}_{2}$ stored in seven top important woody species of Homegarden of Sokoru District; April, 2018.

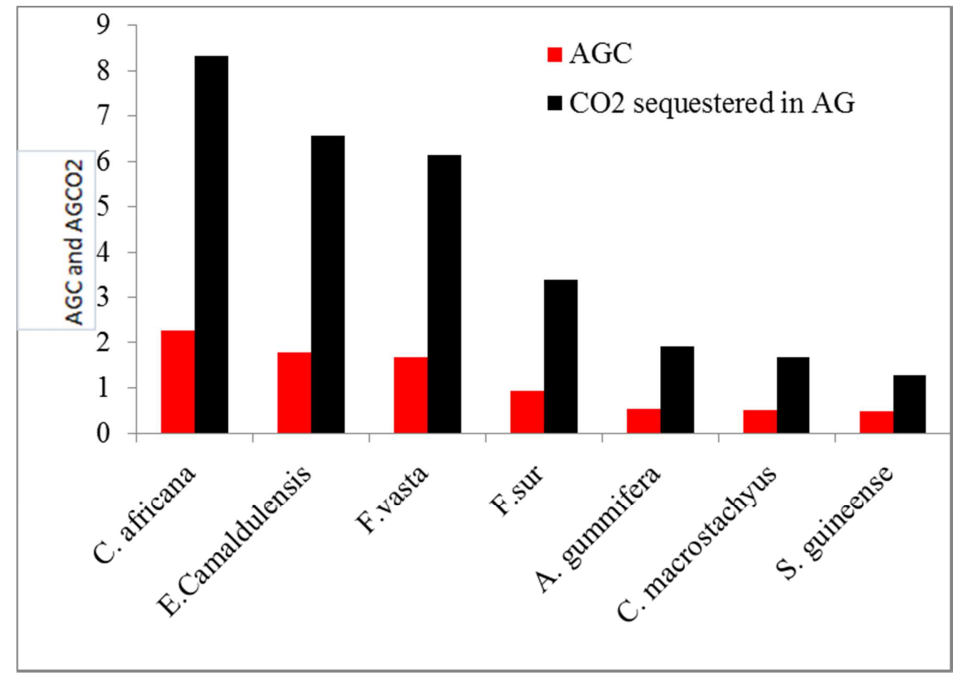

Figure 4. $A G C$ and $\mathrm{CO}_{2}$ in seven top important woody species of cropland land of Sokoru District; April, 2018. 
The top seven species in carbon storage in cropland were C. africana, E. camaldulensis, F. vasta, F. sur, A. gummifera, $C$. macrostachyus and $S$. guineense. Comparatively, $C$. africana, and E. camaldulensis played very important role than any other woody species found in cropland (Figure 4).

The top seven known species by storing carbon and sequestering $\mathrm{CO}_{2}$ in cropland were: F.vasta, C. africana, E. camaldulensis, A.gummifera, A. abyssinica, $C$. macrostachyus and S. guineense. Comparatively, F. vasta and $C$. africana, played very important role in carbon storage and $\mathrm{CO}_{2}$ sequestration than any other woody species found in pastureland (Figure 5).

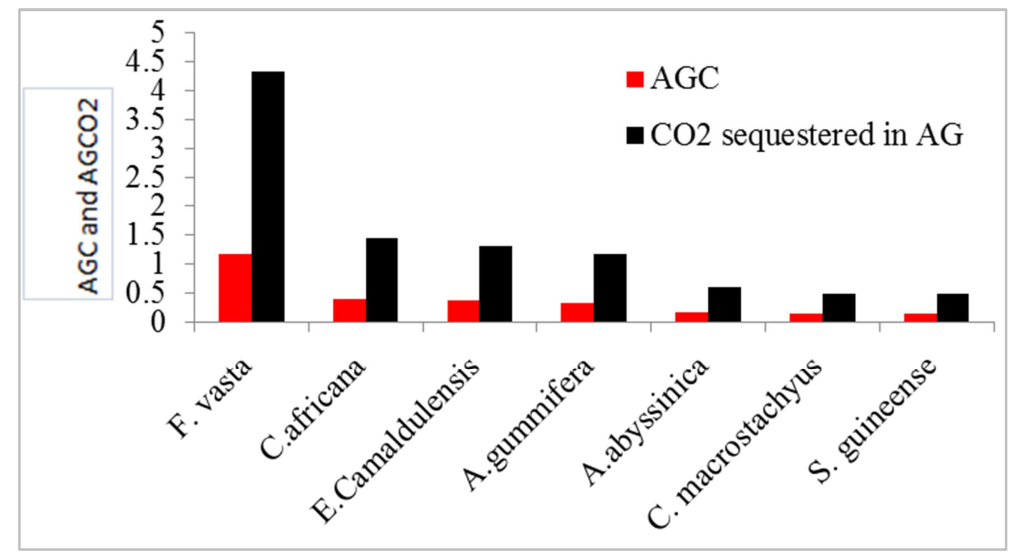

Figure 5. $\mathrm{AGC}$ and $\mathrm{CO}_{2}$ in seven top important woody species of pastureland of Sokoru District; April, 2018.

\subsection{Discussion}

The result of the study indicated that the highest amount of AGC was calculated from the woody species recorded from the cropland followed by homegarden and the least AGC was calculated from pastureland. The most probable reason behind the variation of AGC among the three land use types could be the difference in density (stem count) and DBH, height, and ways of conservation and utilization by the society. This is in line with the study conducted by $[14,27]$ indicating that the agricultural production issues arising from combining trees and pastures, over the past decade or so there has been increasing interest in the role of agroforestry, including silvopastoral systems, as a means of sequestering atmospheric carbon to mitigate the effects of greenhouse gas. The advantage of agroforestry systems compared to forests is that the land can remain in agricultural use whilst sustaining a greater phytomass than a purely arable or pastoral system.

Cordia africana was the most important woody species in carbon storage. They are the most densely populated woody species in cropland followed by homegarden. This showed that Cordia africana in cropland had high density, high DBH and height. Similar study was reported from Jimma by [28] in which cropland with least stem density has got larger biomass following the SFC system, mainly due to the tree $\mathrm{DBH}$. This is an indication that old trees with larger DBH classes are found in the croplands. Almost all the C. africana trees in cropland are matured trees with larger diameter that contributed to the biomass of the trees in the cropland.

From the total AGC (18.03 t/ha) stored in three land use types of the study area, about $17.595 \mathrm{t} / \mathrm{ha}$ or $97.56 \%$ of this carbon was stored in trees. While only $0.438 \mathrm{t} /$ ha or $2.44 \%$ of the AGC was stored in shrubs. This could be due to the lower DBH, richness, density and height of the shrubs, since larger basal area, DBH and height stores large amount of
AGC; the trees of the study area could store large amount of AGC than shrubs. Similar study was reported by [29] the larger diameter woody species stored high amount of AGB, while small amount of AGB has been stored in small diameter class woody species.

The top seven known species by storing carbon and sequestering $\mathrm{CO}_{2}$ in homegarden were C. africana, A. indica, $M$. indica, C. macrostachyus, G. robusta, C. lusitanica and $E$. bureccei. Comparatively, C. africana, and A. indica played very important role than any other woody species found in homegarden. The possible explanation for this result could be due to the higher $\mathrm{DBH}$ and BA of these plant species than any other woody species of the study area. Similar result was reported from Wanago district of Ethiopia by [29] the larger diameter woody species stored high amount of AGB, while small amount of AGB has been stored in small diameter class woody species.

The top seven known species by storing carbon and sequestering $\mathrm{CO}_{2}$ in cropland were, C.africana, E. camaldulensis, $F$. vasta, F.sur, $A$. gummifera, $C$. macrostachyus and S. guineense. Comparatively, C. africana, and E. camaldulensis played very important role than any other woody species found in cropland. This might be due to the higher DBH, height and BA of these species than the others. Since the higher DBH, height, BA and density can store high AGB, these plant species could store high amount of AGB than the lower one. This idea could be supported by the result reported by [29] the larger diameter woody species stored high amount of AGB, while small amount of AGB has been stored in small diameter class woody species

The top seven known species by storing carbon and sequestering $\mathrm{CO}_{2}$ in cropland were F.vasta, C. africana, E. camaldulensis, A. gummifera, A. abyssinica, $C$. macrostachyus and $S$. guineense. Comparatively, F. vasta 
and C. africana, played very important role in carbon storage and $\mathrm{CO}_{2}$ sequestration than any other woody species found in pastureland. The possible explanation for this might be due to the variation of factors like $\mathrm{DBH}$, height and BA among different woody species recorded from the study site.

Table 4. Comparison of carbon storage in current study with others related results.

\begin{tabular}{lll}
\hline Study site & Source & AGCt/ ha \\
\hline Central closed public park in Addis Abeba & Mareshet Tefera & 29.1 \\
Selected church forest in Addis Ababa & Tulu Tolla, 2011 & 128.86 \\
Wenago District, Ethiopia & Talemos Seta and Sebsibe Demisew, 2014 & 16.66 \\
Sub-Saharan Africa & Unru et al., 1993 & 4.5 to 19 \\
Sokoru District, Ethiopia & Current study & 18.03 \\
\hline
\end{tabular}

\section{Conclusion and Recommendation}

About 58 woody species were collected from Sokoru district of which 44 were trees while 14 were shrubs. Most of the AGC calculated from the aboveground biomass was stored in trees mainly due to their high DBH than shrubs.

Of all woody species recorded from the three agroforestry systems, Cordia africana was the most frequent and abundant species with highest basal area. This species also stored the highest aboveground live carbon in its biomass. The woody species of the study area could play an important role in climate change mitigation via photosynthesis. Cropland was the highest land use type in woody species density followed by homegarden.

The woody species found in the study area have great role in carbon storage and $\mathrm{CO}_{2}$ sequestration hence all stakeholders should pay attention for the conservation of trees and shrubs.

People of the study area are conserving woody species found in cropland and homegarden very well than pastureland which indicates, there were over exploitation and lack of conservation in pastureland. Bearing this in mind any concerned body including the local people of the study area should work for the conservation and plantation of the woody species in pasture land

This study was about aboveground live carbon storage of the three land use types (homegarden, cropland and pasture land) and did not include riverine, natural forest and others. Therefore, we recommend further study to fill the above mentioned gaps.

\section{Appendix}

Table A1. AGC and density of woody species in Homegarden.

\begin{tabular}{llll}
\hline Pilots & Altitude & AGC( kg/ha) & Density \\
\hline P1 & 1787 & 480.7407108 & 18 \\
P2 & 1786 & 849.9912348 & 26 \\
P3 & 1718 & 253.4249708 & 17 \\
P4 & 1689 & 132.8347891 & 14 \\
P5 & 1759 & 303.0131156 & 17 \\
P6 & 1756 & 107.0651749 & 15 \\
P7 & 1829 & 79.31518281 & 6 \\
P8 & 1845 & 491.1308156 & 27 \\
P9 & 1901 & 190.090618 & 15 \\
\hline
\end{tabular}

\begin{tabular}{llll}
\hline Pilots & Altitude & AGC( kg/ha) & Density \\
\hline P10 & 1893 & 358.57251 & 12 \\
P11 & 1879 & 598.5155736 & 23 \\
P12 & 1872 & 1117.983206 & 33 \\
P13 & 1886 & 414.033813 & 24 \\
P14 & 1904 & 163.2092391 & 20 \\
Total & & 5539.920954 & 267 \\
\hline
\end{tabular}

Table A2. AGC and density of woody species in Cropland.

\begin{tabular}{llll}
\hline Pilots & Altitude & AGC(kg /ha) & Density \\
\hline P1 & 1790 & 573.2435282 & 22 \\
P2 & 1772 & 998.0579641 & 27 \\
P3 & 1730 & 581.3155669 & 20 \\
P4 & 1697 & 437.8105591 & 14 \\
P5 & 1801 & 245.8416511 & 20 \\
P6 & 1734 & 1377.661379 & 24 \\
P7 & 1798 & 271.7386618 & 18 \\
P8 & 1840 & 2132.068118 & 40 \\
P9 & 1872 & 843.8013698 & 25 \\
P10 & 1882 & 634.664565 & 15 \\
P11 & 1851 & 312.984981 & 15 \\
P12 & 1872 & 195.6848794 & 14 \\
P13 & 1931 & 254.6856387 & 9 \\
P14 & 1912 & 165.9730152 & 7 \\
Total & & 9025.531878 & 270 \\
\hline
\end{tabular}

Table A3. AGC and density of woody species in Pastureland.

\begin{tabular}{llll}
\hline Pilots & Altitude & AGC (kg/ha) & Density \\
\hline P1 & 1784 & 747.9101928 & 8 \\
P2 & 1778 & 24.15448154 & 5 \\
P3 & 1679 & 155.9983287 & 7 \\
P4 & 1701 & 190.9339785 & 9 \\
P5 & 1774 & 97.29002146 & 6 \\
P6 & 1750 & 41.27071766 & 7 \\
P7 & 1796 & 173.8573164 & 10 \\
P8 & 1855 & 761.8719298 & 12 \\
P9 & 1925 & 194.7788975 & 10 \\
P10 & 1879 & 126.2312075 & 7 \\
P11 & 1861 & 114.1444968 & 11 \\
P12 & 1870 & 93.5121423 & 14 \\
P13 & 1917 & 116.5756527 & 19 \\
P14 & 1934 & 626.6045133 & 26 \\
Total & & 3465.133877 & 151 \\
\hline
\end{tabular}




\section{References}

[1] Odum, E. P. (1994). Biosphere: Protecting our global environment, 69: 418-419.

[2] Scott, I., Atwell, B. J., Kriedemann, P. E., Turnbull, C. G. N. (1999). Plants in action: Adaptation in nature, performance in cultivation. Ann Bot 84: 685-687.

[3] CIFOR (2011). Distribution and Characteristics of African Dry Forests and Woodlands. The Dry Forests and Woodlands of Africa Managing for Products and Services, London, Washington, DC, Pp. 288.

[4] Poorter, L., Bongers, F. and Lemmens, R. H. (2004). West African forests: introduction. In: Poorter, L., Bongers, F., Kouamé, F. Y. N. and Hawthorne, W. D. Biodiversity of West African Forests, An Ecological Atlas of Woody Plant Species. Oxon and Cambridge UK and USA, Pp. 521.

[5] Unmubig, B. and Cramer, S. (2008). "Africa in Climate Change". Pp.2.

[6] Brockerhoff, E. G., Jactel H., Parrotta J. A., Quine C. P., Sayer J. (2008). Plantation forests and biodiversity: oxymoron or opportunity? Biodiversity Conservation 17:925-951.

[7] Houghton, R. A. (1999). The annual net flux of carbon to the atmosphere from changes in land use 1850-1990. Tellus Series B Chemical and Physical Meteorology51: 298-313.

[8] Bach, W. (1998). Global warming: The complete briefing. Cambridge University Press, International J Climatol18: 579-580.

[9] Bouriaud, O, Breda, N., Le Moguedec, G., Nepveu, G. (2004). Modelling variability of wood density in beech as affected by ring age, radial growth and climate. Trees - Structure and Function18: 264-276.

[10] Litton, C., Raich, J. and Ryan, M. (2007). Carbon allocation in forest ecosystems. Global Change Biology13: 2089-2109.

[11] Sanchez, P., Buresh, R. and Leakey, R. (1997). Trees, soils, and food security. London Biol. 352: 949-961.

[12] Schroth, G. D., Fonseca, G. A. B., Harvey, C. A., Gascon, C. and Vasconcelos, H. A. N. (2004). Agroforestry and Biodiversity Conservation inTropical Landscapes, Island Press, Washington, D. C, USA.

[13] Dawson, I. K., Lengkeek, A., Weber, J. C. and Jamnadass, R. (2009). "Managing genetic variation in tropical trees: linking knowledge with action in agroforestry ecosystems for improved conservation and enhanced livelihoods," Biodiversity and Conservation. 18 (4): 969-986.

[14] Montagnini, F. and Nair, P. K. R. (2004). Carbon sequestration: An underexploited environmental benefit of agroforestry systems. Agroforestry Systems. 61:281.

[15] Thomson, K. J. (2007). The State of Food and Agriculture 2006: Food Aid for Food Security 145: 415.
[16] Kirby, K. R. and Potvin, C. (2007). Variation in carbon storage among tree species: Implications for the management of a small-scale carbon sink project, 246: 208-221.

[17] Baldocchi, D. (2003). Assessing the eddy-covariance technique for evaluating carbon dioxide exchange rates of ecosystems: past, present and future. Global Change Biology 9: 1-14.

[18] Mac Diken K. G. (2011). A Guide to Monitoring Carbon Storage in Forestry and Agroforestry Prooects, Winrock International, Arlington. Va. USA.

[19] Reichstein, M., Ciais, P., Papale, D., Valentini, R., Running, S., Viovy, N., Cramer, W., Granier, A., Ogee, J. and Allard, V. (2007). Reduction of ecosystem productivity and respiration during the European summer 2003 climate anomaly: a joint flux tower, remote sensing and modeling analysis. Global Change Biology, 13: 634-651.

[20] Brown, S. (1996). Present and potential roles of forests in the global climate change debate. Unasylva, 185: 3-10.

[21] Garrity, D. P. (2004). Agroforestry and the achievement of the millennium development goals. Agroforestry System 61: 5-8.

[22] CSA (2010) Results for Oromia Region, (1): Tables 2.1, 2.5, 3.4 (accessed on $13^{\text {th }}$ January 2018).

[23] Mac Diken K. G. (1997). A Guide to Monitoring Carbon Storage in Forestry and Agroforestry Prooects, Winrock International, Arlington. Va. USA.

[24] Phillips, O., Baker, T., Feldpausch, R. and Brienen, T. (2009). Field manual for plot establishment and remeasurement, Pp. 22 .

[25] Chave, J., Coomes, D., Jansen, S., Lewis, S. L., Swenson, N. G., Zanne, A. E., (2009). Towards a worldwide wood economics spectrum. Ecol. Lett. 12: 351-366.

[26] Chave. J., Réjou-Méchain, M., Búrquez, A., Chidumayo, E., Colgan, M. S., Delitti W. B. C., Duque, T., Eid, P. M., Fearnside, R. C., Goodman, M., Henry, A., Martínez-Yrízar, W. A., Mugasha, H. C., Muller-Landau, M., Mencuccini, B. W., Nelson, A., Ngomanda, E. M., Nogueira, E., OrtizMalavassi, R., Pélissier, P., Ploton, C. M., Ryan, J. G., Saldarriaga, and Vieilledent, G. (2014). Improved allometric models to estimate the aboveground biomass of tropical trees. Global Change Biology, 10: 3177-3190.

[27] Albrecht, A. and Kandji, S. T. (2003). Carbon sequestration in tropical agroforestry systems Agriculture, Ecosystems and Environment, 99: 15-27.

[28] Desalegn Raga and Dereje Denu (2017). Population Density of Cordia africana Lam. across Land Use Gradients in Jimma Highlands, Southwest Ethiopia. International Journal of Sciences:Basic and Applied Research. Vol. 35:2; 61.

[29] Talemos, S. and Sebsebe, D. (2014). Diversity and standing carbon stocks of native agroforestry trees in Wanago district, Ethiopia. Journal of emerging trends in engineering and applied sciences. 5: 125-132. 